ISSN 0258-7122

Bangladesh J. Agril. Res. 37(1): 109-120, March 2012

\title{
ECONOMIC PERFORMANCE OF GINGER (Zingiber officinale Rose.) CULTIVATION IN SOME SELECTED LOCATIONS OF BANGLADESH
}

\author{
Q. M. SHAFIQUL ISLAM ${ }^{1}$, M. A. MATIN ${ }^{2}$ AND S. HosSAIN ${ }^{3}$
}

\begin{abstract}
The study was conducted in two ginger growing districts, namely Nilphamari and Khagrachari of Bangladesh during the period of 2009-10 to estimate the technical efficiency of ginger growers. The study revealed that ginger production was profitable and the average benefit cost ratio (BCR) was found 2.17. The estimated results showed that the average level of technical efficiency among the sample farmers was 85. This implies that given the existing technology and level of inputs, the output could be increased by 15 percent. In inefficiency model, the coefficient of farmer's education and experience in ginger cultivation was negative and significant. Sixty eight percent farmers produced outputs to the maximum frontier output level (81-95\%). Farmers in the study area also mentioned some problems like incidence of root rot disease, high price of seed, insect infestation etc to its production.
\end{abstract}

Keywords: Economic performance of ginger cultivation, technical efficiency of farmers.

\section{Introduction}

Ginger (Zingiber officinale Rose.) is an important commercial spices crop in tropical and subtropical countries including Bangladesh. Among the spices crops, ginger is one of the important cash crops in Bangladesh. In chittagong Hill tracts region, it is a leading cash crop because of its greater potentiality of growing due to suitable climatic condition. The rhizome is used worldwide as spices for flavouring in a number of foods and food-products and also used in medicines (Lawrence 1984; Selvan et al., 2002). It is rich in secondary metabolite, such as oleoresin (Bhagyalakshmi and Singh, 1988). In Bangladesh, it occupies an area of about 8045 hectares with the production of 57095 metric tons (BBS, 2007). It is used in almost all types of curry and is essential in cooking meat. It is found to be used in various pickles, cake and chatni and also used in preparing medicine like ayuratic, homeopathic, and also allopathic. It contains 80 percent water, 2.5 percent albaminoids. 12.3 percent carbohydrate, 1 percent fat, and 1.2 percent minerals (Ahmed, 1976). There are various reasons for the poor yield of ginger in Bangladesh which needs to be identified for appropriate research findings and policy intervention. But very little is known about its production technologies gains at farm level. This lack of information limits the researchers to identify and prioritize research needs and policy makers to adopt proper policy. The

${ }^{1 \& 2}$ Senior Scientific Officer and ${ }^{3}$ Chief Scientific Officer, Agricultural Economics Division, Bangladesh Agricultural Research Institute (BARI), Gazipur, Bangladesh. 
profitability of ginger cultivation in those areas should be measured. Therefore, the present study was undertaken with the following on objectives:

i. to know the existing cultivation practices of ginger;

ii. to analyze the technical efficiencies of the ginger growers, and

iii. to identify the constraints of ginger production in Bangladesh

Table 1. Annual harvest price, area, production and yield of ginger for the period from 1990/91 to 2005/06 in Bangladesh.

\begin{tabular}{c|c|c|c}
\hline Year & Area (ha) & Production MT & Yield (t/ha) \\
\hline $1990-91$ & 7020 & 42680 & 6.08 \\
$1991-92$ & 7059 & 41535 & 5.88 \\
$1992-93$ & 7067 & 41940 & 5.93 \\
$1993-94$ & 7020 & 40160 & 5.72 \\
$1994-95$ & 6907 & 39460 & 5.71 \\
$1995-96$ & 6891 & 38985 & 5.66 \\
$1996-97$ & 6899 & 38750 & 5.62 \\
$1997-98$ & 6913 & 38665 & 5.59 \\
$1998-99$ & 6877 & 38065 & 5.54 \\
$1999-00$ & 6909 & 38265 & 5.54 \\
$2000-01$ & 7296 & 41940 & 5.75 \\
$2001-02$ & 7498 & 42655 & 5.69 \\
$2002-03$ & 7573 & 42825 & 5.66 \\
$2003-04$ & 7917 & 48185 & 6.09 \\
$2004-05$ & 7715 & 49405 & 6.40 \\
$2005-06$ & 8045 & 57095 & 7.10 \\
\hline
\end{tabular}

Source: Price data from DAM, area, production and yield data from various issues of Yearbook of Agricultural Statistics

\section{Methodology}

The study was conducted in two districts, namely one Nilphamari from plain land and another Khagrachari from hilly area during January to April 2009. Kishorgonj Upazila of Nilphamari district and Dighinala Upazila of Khagrachari district were purposively selected for the study. The study areas were selected according to intensive cultivation of ginger production. A total of 100 ginger farmers taking 50 farmers from each districts were randomly selected with the 
help of DAE personnel for interview. Field investigators under the direct supervision of the researchers collected field level cross sectional data using pretested interview schedule. Data were taken on input costs, prices, yields and other necessary information.

Collected data were edited, summarized, tabulated, and analyzed to fulfill the objectives of the study. Tabular methods of analysis using different statistical tools were used in presenting the results of the study. Profitability of ginger production was examined on the basis of gross return, gross margin, and benefit cost analysis. The opportunity cost of family supplied labour was taken into consideration in estimating total cost or full cost. In calculating gross margin, all operating costs were considered as variable cost.

Estimation of technical efficiency: Technical efficiency is the ability of a firm to achieve maximum possible output with available resources. The stochastic Cobb-Douglas production frontier model was used for estimating technical efficiency of ginger producer in the study areas and the model is given below:

$$
\ln Y_{i}=\beta_{0}+\beta_{1} \ln X_{1 i}+\beta_{2} \ln X_{2 i}+\ldots \ldots \ldots \ldots . . .+\beta_{n} \ln X_{n i}+V_{i}-U_{i}
$$

Where, ln represents the natural logarithm; the subscript i represents the $\mathrm{i}$-th farmer in the sample, $Y$ represents the quantity of ginger harvest in kilogram, $X_{i}$ represents the variable factors of production, $\beta \mathrm{i}$ unknown parameters to be estimated, $\mathrm{V}_{\mathrm{i}}$ assumed to be independently and identically distributed (iid) random errors, having $\mathrm{N}\left(0, \sigma_{\mathrm{v}}{ }^{2}\right)$ distribution, $\mathrm{u}_{\mathrm{i}}$ are non-negative one sided random variables, called technical inefficiency effects, associated with the technical inefficiency of production of the farmers involved. It is assumed that the inefficiency effects are independently distributed with a half normal distribution $\left(\mathrm{U} \sim\left|\mathrm{N}\left(0, \sigma_{\mathrm{v}}{ }^{2}\right)\right|\right)$.

To examine the role of relevant farm specific variables in efficiency, the production inefficiency effect model can be written as follows:

$$
\mathrm{Ui}=\delta_{0}+\delta_{1} \mathrm{Z}_{1 \mathrm{i}}+\delta_{2} \mathrm{Z}_{2 \mathrm{i}}+\ldots . .+\delta_{\mathrm{n}} \mathrm{Z}_{\mathrm{ni}}+\mathrm{W}_{\mathrm{i}}
$$

Where, $Z_{i}$ represents the farm specific inefficiency variable factors of production, $\delta_{\mathrm{i}}$ unknown parameters to be estimated, $\mathrm{W}_{\mathrm{i}}$ unobservable random variables, which are assumed to be independently distributed with a positive half normal distribution.

The empirical Cobb-Douglas stochastic frontier production function with double log form can be expressed as:

$$
\begin{aligned}
& \operatorname{Ln} Y_{i}=\beta_{0}+\beta_{1} \operatorname{Ln} X_{1 i}+\beta_{2} \operatorname{Ln} X_{2 i}+\beta_{3} \operatorname{Ln} X_{3 i}+\beta_{4} \operatorname{Ln} X_{4 i}+\beta_{5} \operatorname{Ln} X_{5 i}+\beta_{6} \operatorname{Ln} X_{6 i} \\
& +\beta_{7} \operatorname{Ln} X_{7 i}+\beta_{8} \operatorname{Ln} X_{8 i}+v_{i}-u_{i}
\end{aligned}
$$


Where,

$$
\begin{aligned}
& \mathrm{Ln}=\text { Natural logarithm, } \\
& \mathrm{Y}=\text { Yield of ginger of the } \mathrm{i} \text {-th farm }(\mathrm{kg} / \mathrm{ha}) \\
& \mathrm{X}_{1}=\text { Human labour used by the } \mathrm{i} \text {-th farm (man-days/ha) } \\
& \mathrm{X}_{2}=\text { Land preparation cost used by the i-th farm (Tk./ha) } \\
& \mathrm{X}_{3}=\text { Seed used by the } \mathrm{i} \text {-th farm }(\mathrm{kg} / \mathrm{ha}) \\
& \mathrm{X}_{5}=\text { Urea used by the } \mathrm{i} \text {-th farm }(\mathrm{kg} / \mathrm{ha}) \\
& \mathrm{X}_{6}=\text { TSP used by the } \mathrm{i} \text {-th farm }(\mathrm{kg} / \mathrm{ha}) \\
& \mathrm{X}_{7}=\text { MP used by the } \mathrm{i} \text {-th farm }(\mathrm{kg} / \mathrm{ha}) \\
& \mathrm{X}_{8}=\text { Insecticides cost used by the } \mathrm{i} \text {-th farm }(\mathrm{Tk} . / \mathrm{ha}) \\
& \mathrm{X}_{9}=\text { Irrigation cost used by the } \mathrm{i} \text {-th farm (Tk./ha) } \\
& \mathrm{X}_{10}=\text { Dummy for source of seed } \\
& \beta \text { 's and } \eta \text { 's are unknown parameters to be estimated } \\
& \mathrm{v}_{\mathrm{i}}-\mathrm{u}_{\mathrm{i}}=\text { error term }
\end{aligned}
$$

$\mathrm{V}_{\mathrm{i}}$ are assumed to be independently and identically distributed random errors, having $\mathrm{N}\left(0, \sigma_{v}^{2}\right)$ distribution.

\section{Technical inefficiency effect model}

The $\mathrm{u}_{\mathrm{i}}$ 's in equation (1) are non-negative random variables, called technical inefficiency effects, assumed that to be independently distributed such that the technical inefficiency effects for the $i^{\text {th }}$ farmer, $u_{i}$, are obtained by truncation normal distribution with mean zero and variance $\sigma_{u}^{2}$, such that

$$
u_{i}=\delta_{0}+\delta_{1} z_{1 i}+\delta_{2} z_{2 i}+\delta_{3} z_{3 i}+\delta_{4} z_{4 i}+\delta_{5} z_{5 i}+W_{i}
$$

where,

$$
\begin{aligned}
& \mathrm{z}_{1}=\text { Land size of the i-th farm operator (ha) } \\
& \mathrm{z}_{2}=\text { Age of the i-th farm operator (years) } \\
& \mathrm{z}_{3}=\text { Education of the i-th farm operator (year of schooling) } \\
& \mathrm{z}_{4}=\text { Experience in ginger farming of the i-th farm operator (year) } \\
& \mathrm{z}_{5}=\text { Family size of the ginger growers of i-th farm operator (number) } \\
& \delta \text { 's are unknown parameters to be estimated }
\end{aligned}
$$

$\mathrm{W}_{\mathrm{i}}$ are unobservable random variable or classical disturbance term, which are assumed to be independently distributed, obtained by truncation of the normal distribution with mean zero and unknown variance $\sigma^{2}$, such that $u_{i}$ is nonnegative.

The $\beta, \eta$ and $\delta$ coefficients are unknown parameters to be estimated, together with the variance parameters which are expressed in term of

$$
\begin{aligned}
\sigma^{2} & =\sigma_{u}^{2}+\sigma_{v}^{2} \\
\text { and } \quad \gamma & =\sigma_{u}^{2} / \sigma^{2}
\end{aligned}
$$


$\gamma$ is the ratio of variance of farm specific technical efficiency to the total variance of output and has a value between zero and one.

The estimates for all parameters of the stochastic frontier (1) and inefficiency model (2) were estimated in a single stage by using the Maximum Likelihood (ML) method. The econometric computer software package FRONTIER 4.1 (Coelli, 1996) was applied to estimate the parameters of stochastic frontier models using the ML.

\section{Results and Discussion}

\section{Agronomic performance}

On an average, 6.28 number of ploughings and 4.10 number of ladderings were done by the farmers of Nilphamari for ginger cultivation. But the farmers of Khagrachari prepared their land by 2.06 number of spaddings (Table 2). Eighty six percent farmers used insecticides. It was observed that all the farmers of Nilphamari used insecticides. Sowing period ranged from $3^{\text {rd }}$ week of April to $1^{\text {st }}$ week of June in Nilphamari and the farmers of Khagrachari completed their sowing from $3^{\text {rd }}$ week of April to $4^{\text {th }}$ week of May . It was also observed that $50 \%$ farmers completed their sowing within the month of April, $43 \%$ at the end of May and rest $7 \%$ farmers sown their land in the month of June.

Table 2. Agronomic practices of ginger cultivation of the sample farmers in the study areas.

\begin{tabular}{l|c|c|c}
\hline Activities & Nilphamari & Khagrachari & All \\
\hline Ploughing (average) & 6.28 & - & - \\
Spadding (average) & - & 2.06 & - \\
Laddering (average) & 4.10 & - & - \\
Weeding (average) & 3.72 & 2.32 & 3.02 \\
Earthing (average) & 2.98 & 0.10 & 1.54 \\
Insecticide application (\%) & 100 & 72 & 86 \\
Irrigation (\%) & 72 & - & 36 \\
Sowing (\%): & & & \\
$\quad$ April & 36 & 64 & 50 \\
May & 50 & 36 & 43 \\
$\quad$ June & 14 & - & 7 \\
Weeding number (\%): & & & \\
$\quad$ One & - & 8 & 4 \\
Two & - & 54 & 27 \\
Three & 42 & 38 & 40 \\
Four & 42 & - & 21 \\
$\quad$ Five & 16 & - & 8 \\
\hline
\end{tabular}


All the farmers followed the method of line sowing. Weeding in ginger field was done by all the farmers. All the farmers in both the areas weeded their land ranging from one to five weedings. The farmers of Nilphamari weeded their land ranges from three to five times, but the farmers of Khagrachari weeded only one to three times.

\section{Input use pattern}

The pattern of input use is presented in Table 3. On an average, ginger farmers used 267 man-days of human labour per hectare of which $45 \%$ were family supplied. The farmers of Nilphamari used higher human labour (299 man-days/ha) compared to Khagrachari farmers (235 man-days/ha). It was due to increased number of labour used for more cowdung application and better management practices. On an average, $1271 \mathrm{~kg}$ of seed was used per hectare which was found higher in Nilphamari than Khagrachari. The farmers used 75\% seed from their own sources. On an average, farmers used $5310 \mathrm{~kg}$ manures/ha, which was more in Nilphamari and very little amount was used in Khagrachari. Farmers in the study areas also used chemical fertilizers like urea, TSP, and MP at the rate of $122 \mathrm{~kg}$, $137 \mathrm{~kg}$, and $145 \mathrm{~kg}$ per hectare, respectively. It was much lower than the recommended doses of i.e., urea (300-320) kg/ha, TSP (260-280) kg/ha, and MP (290-310) $\mathrm{kg} / \mathrm{ha}$ (Modern cultivation practices of ginger in the hilly areas, 2009).

Table 3. Level of input use per hectare for ginger cultivation in the study areas.

\begin{tabular}{lcccc}
\hline Type of input & Nilphamari & Khagrachari & All \\
\hline Human labour (man-days): & 299 & 235 & 267 \\
Own & 84 & 154 & 119 \\
Hired & 215 & 81 & 148 \\
Land preparation cost (Tk./ha & 11004 & $19033(169)^{*}$ & 15019 \\
Seed (kg./ha): & 1467 & 1075 & 1271 \\
Own & 1094 & 808 & 951 \\
Purchased & 373 & 267 & 320 \\
Manures (kg/ha): & 9445 & 1175 & 5310 \\
Own & 6026 & 879 & 3452 \\
Purchased & 3419 & 296 & 1858 \\
Oilcake & 24 & - & 12 \\
Fertilizers (kg/ha): & & & \\
Urea & 143 & 101 & 122 \\
TSP & 223 & 51 & 137 \\
MP & 282 & 7 & 145 \\
Zn & 4 & - & 2 \\
Zipsum & 10 & - & 5 \\
Insecticides (Tk.) & 7363 & 2120 & 4742 \\
Irrigation (Tk.) & 3085 & - & 1543 \\
\hline
\end{tabular}

*Parentheses indicates the number of labour used for land preparation 
The Nilphamari farmers used more fertilizers than Khagrachari. They also used small amount of Zn, Oilcake, and Zipsum which were absent in Khagrachari farmers. Insecticides were used in both areas, but it was more than three times used in Nilphamari. Only the farmers of Nilphamari used irrigation for ginger production.

\section{Cost of ginger production}

The cost of production included different variable cost items like land preparation, human labour, seed, manure, fertilizer, insecticides, irrigation, interest on operating cost and rental value of land. Both cash expenditure and imputed value of family supplied inputs were included in the analysis and shown in Table 4.

Table 4. Cost of ginger cultivation by the sample farmers in the study areas.

\begin{tabular}{l|c|c|c} 
& \multicolumn{3}{c}{ (Taka per ha) } \\
\hline Cost items & Nilphamari & Khagrachari & All area \\
\hline Land preparation: & 11004 & 19033 & $15019(7)$ \\
Own & 8738 & 11375 & 10057 \\
Hired & 2266 & 7658 & 4962 \\
Human labour: & 35888 & 26334 & $31112(17)$ \\
Own & 10107 & 17316 & 13712 \\
Hired & 25781 & 29018 & 17400 \\
Seed: & 138549 & 54133 & $96341(51)$ \\
Own & 103230 & 40655 & 71943 \\
Purchased & 35319 & 13478 & 24398 \\
Mulching materials: & 5581 & - & $2791(1)$ \\
Own & 3614 & - & 1807 \\
Purchased & 1968 & - & 984 \\
Manures: & 4723 & 588 & $2656(2)$ \\
Own & 3013 & 440 & 1727 \\
Purchased & 1710 & 148 & 929 \\
Oilcake & 826 & - & 413 \\
Fertilizers: & 18344 & 3500 & $10922(6)$ \\
Urea & 1718 & 1212 & 1465 \\
TSP & 10172 & 2029 & 6100 \\
MP & 4895 & 259 & 2577 \\
Zn & 325 & - & 163 \\
Zipsum & 408 & - & 413 \\
Insecticides & 7363 & 2120 & $4742(3)$ \\
Irrigation & 3085 & - & $1543(1)$ \\
Interest on operating & 10296 & 5583 & $8093(4)$ \\
capital (8\% for one year) & & & \\
Land use cost & 17154 & 11250 & $14538(8)$ \\
Total cost: & 128702 & & \\
Cash cost basis & 251988 & 122541 & 187602 \\
Full cost basis & & &
\end{tabular}

Figures in the parentheses are percentage of total cost. 
It revealed that highest cost was incurred for seed $(51 \%)$ followed by human labour (17\%), land use cost (8\%), land preparation (7\%), and fertilizers $(6 \%)$ when family supplied inputs were valued at market rate. Mulching cost was only observed in Nilphamari. It was also found that all the farmers used straw as a mulching material.

In Khagrachari, land preparation cost was found more than 1.5 times from Nilphamari. Because the farmers of Khagrachari prepared their land by cutting the trees, firing, cleaning and then spading by human labour. Seed cost was observed more in Nilphamari, it was due to more seed rate and high price of seed. The average cost of production in full cost basis was found Tk. 187602/ha, which was found more than two times higher in Nilphamari. Because all costs except land preparation were observed higher in Nilphamari.

\section{Profitability}

Table 5 depicted that the sample farmers received on an average $7886 \mathrm{~kg} / \mathrm{ha}$ of ginger. Though the main yield was found higher in Khagrachari, when the yield of mother rhizome (1142) $\mathrm{kg} / \mathrm{ha}$ was included higher yield was observed in Nilphamari. Similar amount of mother rhizome and more than $2 \mathrm{t} /$ ha less amount of main yield was found by the farmers of Nilphamari (Ahmed, 1990). The average gross return from ginger production was found Tk. 407912/ha and gross margin on full cost basis Tk. 220310/ha.

Table 5. Profitability of ginger cultivation in the study areas.

\begin{tabular}{lcccc}
\hline Items & Nilphamari & Khagrachari & All \\
\hline Main yield (kg/ha) & 7064 & 7566 & 7315 \\
Yield of mother rhizome (kg/ha) & 1142 & - & 571 \\
Total yield (kg/ha) & 8206 & 7566 & 7886 \\
Gross return (Tk./ha) & 461450 & 354373 & 407912 \\
Total cost (Tk./ha): & & & \\
Cash cost basis & 128702 & 88853 & 101167 \\
Full cost basis & 251988 & 122541 & 187602 \\
Gross margin (Tk./ha): & & & \\
Cash cost basis & 332748 & 280741 & 306745 \\
$\quad$ Full cost basis & 209462 & 231832 & 220310 \\
Benefit cost ratio: & & & \\
Cash cost basis & 3.59 & 5.08 & 4.11 \\
Full cost basis & 1.83 & 2.89 & 2.17 \\
Cost of ginger (Tk./kg): & & & \\
Cash cost basis & 15.68 & 9.73 & 12.58 \\
Full cost basis & 30.71 & 16.20 & 23.79 \\
Return from ginger (Tk./kg) & 56.23 & 46.84 & 51.73 \\
\hline
\end{tabular}

Source : Field survey 2010 
The benefit cost ratio was estimated at 4.11 and 2.17 on cash cost basis and full cost basis, respectively. Total cash cost was found higher in Nilphamari due to more inputs used which was discussed earlier. As a result, benefit cost ratio was lower in Nilphamari on both cash and full cost basis. The cost of grain was Tk. 12.58 on cash cost basis and Tk. 23.79 on full cost basis. On an average, benefit from per kilogram ginger production was Tk. 51.73 .

\section{Maximum likelihood estimates of farm specific stochastic frontier production function and inefficiency model}

The maximum likelihood estimates for parameter of the Cobb Douglas Stochastic production function frontier of ginger was presented in Table 6. Most of the parameters were statistically significant and positive. The empherical result indicated that the co-efficient of human labour and cowdung use were found positive and significant at 5 percent level, while use of urea was found positive but significant at 10 percent level. In other words, the co-efficient of human labour, cowdung, and urea were $0.041,0.624$, and 0.104 , respectively.

Table 6. Maximum likelihood estimates of the stochastic Cobb-Douglas frontier production function and technical inefficiency model for ginger.

\begin{tabular}{|c|c|c|c|c|}
\hline Independent variables & Parameters & Coefficient & Standard Error & t-ratio \\
\hline \multicolumn{5}{|l|}{ Stochastic frontier: } \\
\hline Constant & $\beta_{0}$ & $3.25^{* * *}$ & 1.09 & 2.98 \\
\hline Ln Human labour (man-days/ha) & $\beta_{1}$ & $0.041 * *$ & 0.019 & 2.10 \\
\hline Ln Land preparation (Tk/ha) & $\beta_{2}$ & -0.459 & 0.402 & -1.14 \\
\hline Ln Seed (Tk./ha) & $\beta_{3}$ & 0.245 & 0.182 & 1.35 \\
\hline Ln Cowdung (Tk./ha) & $\beta_{4}$ & $0.624 * *$ & 0.249 & 2.50 \\
\hline Ln Urea (kg/ha) & $\beta_{5}$ & $0.104 *$ & 0.061 & 1.71 \\
\hline Ln TSP (kg/ha) & $\beta_{6}$ & 0.499 & 0.324 & 1.52 \\
\hline Ln MoP(Tk./ha) & $\beta_{7}$ & -0.172 & 0.118 & -1.45 \\
\hline Ln Insecticides (Tk./ha) & $\beta_{8}$ & 0.386 & 0.357 & 1.08 \\
\hline Dummy for source of seed & $\beta_{9}$ & 0.419 & 0.398 & 1.03 \\
\hline \multicolumn{5}{|l|}{ Technical inefficiency model: } \\
\hline Constant & $\delta_{0}$ & 0.0315 & 0.029 & 1.06 \\
\hline Age & $\delta_{1}$ & 0.117 & 0.093 & 1.28 \\
\hline Education & $\delta_{2}$ & $-0.235^{*}$ & 0.131 & -1.80 \\
\hline Experience & $\delta_{3}$ & $-0.319 * *$ & 0.153 & -2.08 \\
\hline Family size & $\delta_{4}$ & 0.173 & 0.138 & 1.25 \\
\hline \multicolumn{5}{|l|}{ Variance parameters: } \\
\hline Sigma-squared & $\sigma^{2}$ & 0.320 & & 0.097 \\
\hline Gamma & $\gamma$ & 0.978 & & 0.562 \\
\hline Log likelihood function & & & 195 & \\
\hline
\end{tabular}

$* * *, * *$ and $*$ indicate the significant at $1 \%, 5 \%$, and $10 \%$ level of probability, respectively. 
It implied that this inputs had a significant and positive impact on ginger production. The yield of ginger would increase by $0.041,0.624$, and 0.104 percent if farmers apply $1 \%$ additional human labour, cowdung, and urea, respectively. The technical in-efficiency model, the co-efficient of farmers education and experience was negative and significant. It means that technical inefficiency in ginger production decreases with the increase in farmers education and experience. Similar observation was found in various earlier studies (Coelli and Battese, 1996, Sharif and Dhar 1996, Seyoum et al., 1998.

The estimated value of variance $\left(\sigma^{2}\right)$ was significantly different form zero which indicated a good fit and correctness of specified distributional assumption.

\section{Technical efficiency and its distribution}

It is evident from Table 7 that the mean value of technical efficiency was 0.85 with a range from 0.61 to $0.95 \%$. About $68 \%$ farmers produced outputs which were very close to the maximum frontier output level (81-95\%). This implies that on an average, the ginger growers in the study areas were producing ginger about 85 percent of potential frontier production levels, given the levels of their inputs and the technology currently being used. This also indicated that there existed an average level of technical inefficiency of 15 percent.

Table 7. Technical efficiency of ginger growers in the study areas.

\begin{tabular}{lcc}
\hline \multicolumn{1}{c}{ Technical efficiency level } & No of farmers & \% of total farmers \\
\hline $61-70$ & 15 & 15 \\
$71-80$ & 17 & 17 \\
$81-90$ & 21 & 21 \\
91 and above & 47 & 47 \\
Mean efficiency & & 0.85 \\
Maximum & & 0.95 \\
Minimum & & 0.61 \\
\hline
\end{tabular}

\section{Constraints}

Although yield of ginger was low but also observed a profitable crop, there are several constraints to its higher production. The constraints are shown in Table 8 . It was found that all the farmers responded incidence of root rot disease ranked first as a problem of ginger production. Other major constraints were high price of seed, insect infestation, lack of capital etc. were also opined by the ginger farmers. 
Table 8. Constraints to ginger cultivation in the study areas.

\begin{tabular}{l|c|c|c|c}
\hline \multirow{2}{*}{ Items } & \multicolumn{3}{|c|}{ Percent farmers' responded } & \multirow{2}{*}{ Rank } \\
\cline { 2 - 4 } & Nilphamari & Khagrachari & All & \\
\hline Incidence of root rot diseases & 100 & 94 & 97 & 1 \\
High price of seed & 72 & 44 & 58 & 2 \\
Insect infestation & 58 & 46 & 52 & 3 \\
Lack of capital & 42 & 58 & 50 & 4 \\
Insecticides not work properly & 58 & 28 & 43 & 5 \\
Lack of quality seed & 46 & 34 & 40 & 6 \\
High price of fertilizers & 34 & 26 & 30 & 7 \\
High price of insecticide & 38 & 18 & 28 & 8 \\
Others* & 32 & 22 & 27 & 9 \\
\hline
\end{tabular}

* It means excess weed, lack of labour and timely rainfall.

\section{Conclusion and Recommendations}

The ginger production in the study areas is profitable. Ginger farmers received high return on its investment, but it did not reach the optimum level. Appropriate level of input use and time of operation is essential for achieving higher yield and profits, but the technology employed by the farmers were not at the level of recommendation. The estimated technical efficiency for ginger varies from 61 to $95 \%$, with an average efficiency $85 \%$. This implies that the output per farm can be increased, on an average, $15 \%$ without incurring any additional production cost. The co-efficient of human labour, cowdung, and use urea of were found positive and significant. The coefficients of farmer's education and experience were negative and significant. Most of the farmers produced output to the maximum frontier output level (81-95\%).

Availability of modern variety seed and production technology to the farmers, yield and production can be increased which may help to increase their income.

- Farmers require fair price of seed, fertilizers and insecticides.

- Farmers desire to get quality seed, disease and insect tolerant variety for getting higher return from ginger production.

\section{References}

Ahmed, M. and Shaha, J. K. 1990. Ginger Cultivation in Bangladesh. An Agro-Economic Profile and Constraints to its higher Production at Farm Level. Agricultural Economics Division, BARI, Joydebpur, Gazipur. Research Report No. 10. 
BBS. 2007. Bangladesh Bureau of Statistics, Statistical Yearbook of Bangladesh, Statistics Division, Ministry of Planning, GOB, Bangladesh.

Bhagyalakshmi A., N. S. Singh. 1988. Meristem culture and micro propagation of variety of ginger (Zingiber officinale Rose). With a high yield of Oleoresin. J. Hort. Sci. 63:321-32.

Coelli, Tt. and G., Battese. 1996. Identification of factors which Influence the Technical Inefficiency of Indian Farmers. Australian J. Agril. Econ. 40(2): 103-128.

Lawrence, B.M. 1984. Major tropical spices- Ginger (Zingiber Officinale Rose.). Perfumer \& Flavorist 9: 1-40.

Seyoum, E.T., Battese, G.E. and Fleming, E.M. 1998. Technical Efficiency and Productivity of Maize Producers in Eastern Ethiopia: A study of Farmers within and outside.

Sharif, N.R. and Dar, A.A. 1996. Stochastic Frontiers and Technical Efficiency Distributions: An Analysis Based on Rice Farming Data for Bangladesh. Canadian J. Econ. 29 (Special Issue): 582-586. 